\begin{tabular}{ll}
\hline 薬 & 物 \\
\hline
\end{tabular}

\title{
頭頸部悪性腫痬に対する油性ブレオマイシン 局注療法
}

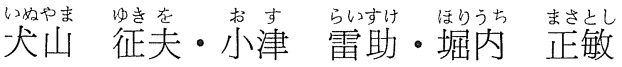

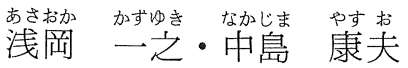

\section{1.はじめに}

当教室においては1967年10月以来，200例を越える頭頸部悪性腫晹に対し，Bleomycin（以下 B LM 上略す）による治療を括てない，その臨床効果及び病理組織学的効果につき検討を抢てなって きた (123145)6) その結果 B LMは単独又は放射線との併用による術前治療として或いは放射線との併 用による根治治療として頭頸部悪性腫痬の治療体系の中に組み入れられるようになった。一方 B L $\mathrm{M}$ の投与方法としては，乙れ迄，動注，静注，局注，固形，軟膏などによりおてなわれている. 当 教室における治療経験からは動注が最も効果的であることが示された。最近，国立がんセンターの 木村はB LMの持続製剤として油性ブレオマシン（ブレオマイシンの分散剤入りゴマ油けんだく 液）を開発した。そこで当教室においても昭和50年 5 月より再発癌を中心とする 頭頸部悪性腫瘍 20 例について本剂による局注療法を抏てないその一次効果につき若干の知見を得たので報告する。

\section{2. 治 療 対 象}

治療対象は炤和 50 年 5 月 1 日より炤和 50 年 10 月31日迄の期間に慶大耳鼻科に入院又は腫瘍外 来に括いて治療をおてなった20症例である。疾 患の内訳は上顎癌 6 例，上栶頭癌及び口蓋癌各
3 例, 碉桃癌, 舌癌, 㗱頭癌各 2 例, 上顎肉 腫, 口腔底癌各 1 例である。乙の内, 新鮮例は 4 例（症例10，11，12，19）のみで残りはすべ て再発癌である。

\section{3. 投与方法及び効果判定}

油性 B LMは $1 \mathrm{ml}$ 中にB LM15mg力価を含有 しており， 1 回の注射には $15 \sim 30 \mathrm{mg}(1-2$ $\mathrm{ml}$ ）を使用した。局注部位は腫瘍の大きさなど にもよるが原則として腫痬の周囲より $3 \sim 4$ 力 所に分けて注射をおてなった，尚症例によって
は腫痬内に注射を抢てなったものもある．局注 の間隔は週 1 回を原則とし, 症例によっては週 2 回局注をおてなったものあある。はじめの内 は油性 B LMを直接局注していたが疼痛を訴え る症例屯多いため, 途中から油性 B LM局注前 
に予め $0.5 \%$ キシ・ロカインによる浸潤麻酔をお こなった。

効果判定の方法としては腫痬が $80 \%$ 以上縮小
したものを著効，30〜80\%程度の縮小を有效， 腫瘍の縮小が30\%以下か自覚症改善のみの屯の をやや有効とした。

\section{4. 治 療 成 績 （表 1)}

20 症例についての一次効果をみると著効は 6 例で著効率30\%，次いで有効 6 例 (30\%)，や や有効 2 例 (10\%)，無効 6 例（30\%）であっ た．有効以上を効果があったものと判定すると
有効率は60\%となる（表 2 ）。疾患之効果之の 関係についてみると著効 6 例中 4 例が口腔癌又 は中咽頭癌であり，2 例が上䕱癌であった．次 に有効例では上顎癌が 2 例で以下，上咽頭癌，

表 ।

\begin{tabular}{|c|c|c|c|c|c|c|c|c|}
\hline & $\mid$ 症例| 年令 & 名 & 組織診断 & 投与方法 & 効果 & 既 治 療 & 副作用 & 備 \\
\hline 1 & $\hat{\rho}$ & 上顎癌再発 & 扁平上皮癌 & $105 \mathrm{mg} / 6$ 回 $/ 36$ 日 & 著効 $\mathrm{I}$ & $\begin{array}{l}\text { BLM. Linac. } \\
\text { 上頢部切 }\end{array}$ & $\begin{array}{l}\text { 疼痛, 全身 } \\
\text { 倦㥐感 }\end{array}$ & 経過良好 \\
\hline 2 & 0. . & " & " & $90 \mathrm{mg} / 6$ 回/43日 & " $\mathrm{F}$ & $\begin{array}{l}\text { BLM. Linac. } \\
\text { 上顎全摘 }\end{array}$ & なし & " \\
\hline 3 & 0. 占 & "I & " & $180 \mathrm{mg} / 10$ 回/78日 & 有効 & $\begin{array}{l}\text { BLM. Linac. } \\
\text { 上頢部切 }\end{array}$ & $\begin{array}{l}\text { 疼痛, 食思否 } \\
\text { 振, 全身供意 }\end{array}$ & 3 力月後死亡 \\
\hline 4 & 2. $\hat{0}$ & " & " & $150 \mathrm{mg} / 10$ 回/31日 & " $\mathrm{F}$ & $\begin{array}{l}\text { BLM.5FU.Linac } \\
\text { 上顎全摘 }\end{array}$ & c澄熱, 全身倦 & 2 力月後死亡 \\
\hline 5 & 9. 우 & " & "I & $105 \mathrm{mg} / 6$ 回/64日 & やや & $\begin{array}{l}\text { BLM. Linac. } \\
\text { 上顎部切 }\end{array}$ & 発熱, 疼痛 & $\begin{array}{l}\text { 広汎性全摘及 } \\
\text { び顔面形成術 }\end{array}$ \\
\hline 6 & 7. $\hat{o}$ & "1 & " & $45 \mathrm{mg} / 3$ 回/ 8 日 & 無効 5 & $\begin{array}{l}\text { 5FU. Linac. } \\
\text { FT-207 }\end{array}$ & 疼痛 & 3 力月後死亡 \\
\hline 7 & 3. $\hat{0}$ & 上顎肉腫再発 & $\begin{array}{l}\text { neurogenic } \\
\text { sarcoma }\end{array}$ & $90 \mathrm{mg} / 6$ 回 $/ 28$ 日 & " & $\begin{array}{l}\text { 上顎部切.ADM. } \\
\text { Linac. }\end{array}$ & なし & 3 力月後死亡 \\
\hline 8 & $\hat{0}$ & 上咽頭癌再発 & 扁平上皮癌 & $45 \mathrm{mg} / 3$ 回 $/ 35$ 日 & "I & Linac、頸廓 & なし & $\begin{array}{l}\text { Gold·grain } \\
\text { 刺入 }\end{array}$ \\
\hline 9 & 2. 우 & " & 未分化癌 & $60 \mathrm{mg} / 4$ 回 $/ 22$ 日 & 有効 $\mathrm{E}$ & $\begin{array}{l}\text { BLM. Linac. } \\
\text { 頸廓 }\end{array}$ & 全身倦含感 & $\begin{array}{l}\text { 全身状態 } \\
\text { 良 }\end{array}$ \\
\hline 10 & . $\hat{0}$ & 口蓋癌 & 扁平上皮癌 & $75 \mathrm{mg} / 3$ 回 $/ 22$ 日 & 著効 $\mid \mathrm{E}$ & BLM. $\mathrm{Co}^{60}$ & 疼痛 & 経過良好 \\
\hline 11 & 5. $\hat{0}$ & 舌 癌 & " & $45 \mathrm{mg} / 3$ 回 $/ 15$ 日 & " & なし & なし & $\mid \begin{array}{c}\mathrm{T}_{1} \mathrm{~N}_{0} \mathrm{M}_{0} \\
\text { 経過良好 }\end{array}$ \\
\hline 12 & $\hat{0}$ & 口腔底癌 & " & $60 \mathrm{mg} / 3$ 回 $/ 13$ 日 & " & なし & $\begin{array}{l}\text { 発熱, 疼痛, } \\
\text { 食思不振 }\end{array}$ & $\begin{array}{l}\mathrm{T}_{2} \mathrm{Na}_{1} \mathrm{M}_{0}, \text { 一 } \\
\text { 部Linac 併用 }\end{array}$ \\
\hline 13 & . $\hat{0}$ & 口蓋癌再発 & " & $45 \mathrm{mg} / 3$ 回 $/ 15$ 日 & $/ 1 \mathrm{E}$ & BLM. Linac. & 疼痛 & 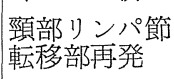 \\
\hline 14 & . 우 & 扁桃癌再発 & " & $45 \mathrm{mg} / 3$ 回 $/ 15$ 日 & 無効 $\mathrm{E}$ & $\begin{array}{l}\text { BLM. Linac. } \\
\text { FT-207 }\end{array}$ & 疼痛 & $\begin{array}{l}\text { Gold·grain } \\
\text { 刺入 }\end{array}$ \\
\hline 15 & $\hat{\delta}$ & " & " & $120 \mathrm{mg} / 4$ 回 $/ 12$ 日 & 有効 $\mathrm{E}$ & $\begin{array}{l}\text { BLM.5FU.MMC } \\
\text { ADM. Linac. }\end{array}$ & 全身倦忿感 & 2 週間後 \\
\hline 16 & & $\begin{array}{l}\text { 口荎癌再.発 } \\
\text { 皮転移 }\end{array}$ & " & $255 \mathrm{mg} / 12$ 回/ 85 日 & & 腫湯切除, Linac. & $\begin{array}{l}\text { 登熱, 疼痛, } \\
\text { 食不振など }\end{array}$ & 2 力月後死亡 \\
\hline 17 & $\hat{o}$ & $\begin{array}{l}\text { 喉頭癌再発 } \\
\text { 钼部転移 }\end{array}$ & "I & $90 \mathrm{mg} / 3$ 回 $/ 13$ 日 & & $\begin{array}{l}\text { 喉頭全摘, 多剂併 } \\
\text { 等 }-422\end{array}$ & 発 熱 & 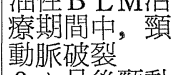 \\
\hline 18 & & " & " & $165 \mathrm{mg} / 7$ 回/64日 & 無効豆 & $\begin{array}{l}\text { 頭喉全摘, 頸廓 } \\
\text { Linac. }\end{array}$ & 食思不振 & $\begin{array}{l}3 \text { 力月後頸動 } \\
\text { 脈破裂纪死 }\end{array}$ \\
\hline 19 & & $\begin{array}{l}\text { 上咽頭癌 } \\
\text { 頸部転移 }\end{array}$ & " & $90 \mathrm{mg} / 6$ 回 $/ 85$ 日 & $\mid \begin{array}{l}\text { 有效 } \\
\mid\end{array}$ & Linac. & なし & $\begin{array}{l}\text { 綴過良好 } \\
4 \text { 力月後頸動 }\end{array}$ \\
\hline 20 & $\hat{0}$ & $\begin{array}{l}\text { 舌癌再発 } \\
\text { 䣆部転移 }\end{array}$ & " & $165 \mathrm{mg} / 6$ 回 $/ 43$ 日 & 無効 & $\begin{array}{l}\text { 舌半側切除, 頸 } \\
\text { Linac. BLM. }\end{array}$ & $\begin{array}{l}\text { 發熱, 疼痛, } \\
\text { 食思不振など }\end{array}$ & 脈破裂红て死 \\
\hline
\end{tabular}


表 2 一次効果

\begin{tabular}{cc|cc} 
著 & 効 $(>80 \%)$ & 6 & $(30 \%)$ \\
有 効 $(30-80 \%)$ & 6 & $60 \%$ \\
\hline やや有効 症状の改善 & 2 \\
無 効 & 6 \\
\hline 計 & 20
\end{tabular}

扁桃癌，口蓋癌皮膚転移，㗱頭癌頸部転移例が 各 1 例であった（図 1 ）。一方投与量と効果之 の関係についてみると末だ例数が少ないためは っきりしたことは云えないが，著効例での平 均投与量は $70 \mathrm{mg}$ であり，有効例の平均投与量 $142.5 \mathrm{mg}$ と比較すると約半分の投与量ですんで いる. これに対し無効例での平均投与量む 92.5 $\mathrm{mg}$ と比較的少ないが，乙の内 3 例は 3 回注射の 時点で疼痛がつよく中止した症例でありむしろ 判定不能例に入れてあよい症例が含まれている

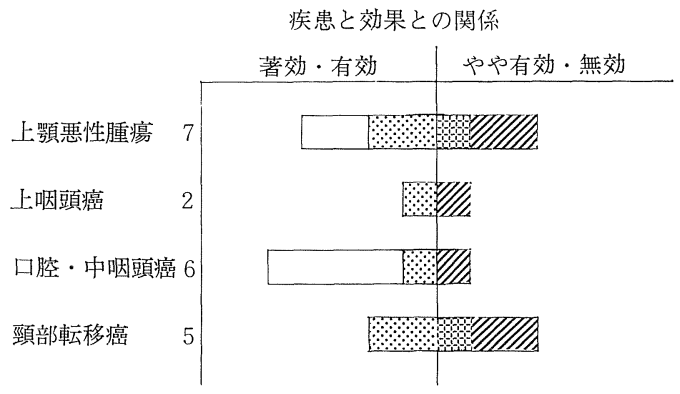

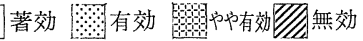

図 I

5. 症

症例 1 .

67才 男性

診断：右上顎癌（中等度分化型扁平上皮癌）, $\mathrm{T}_{3} \mathrm{~N}_{0} \mathrm{M}_{0}$

治療：昭和 50 年 2 月 8 日より B LM静注 $120 \mathrm{mg}$ と Linac, $2800 \mathrm{R}$ 照射とを併用し腫惕は著明に 縮小したが上顎部分切除術(Denker 手術) を施 行した。昭和 50 年 5 月 21 日診察時, 上顎洞側壁 に腫愓状膨浲をみとめ再発であることを確認し
ためと考えられる（図 2 )。 また腫演の大きさ と効果之の関係についてみると著効例では腫陽 の平均直径は $13.7 \mathrm{~mm}$ でり，小さい腫濼の方が 効果が大きいという傾向を示した（図 3 ).

投与量と効果との関係

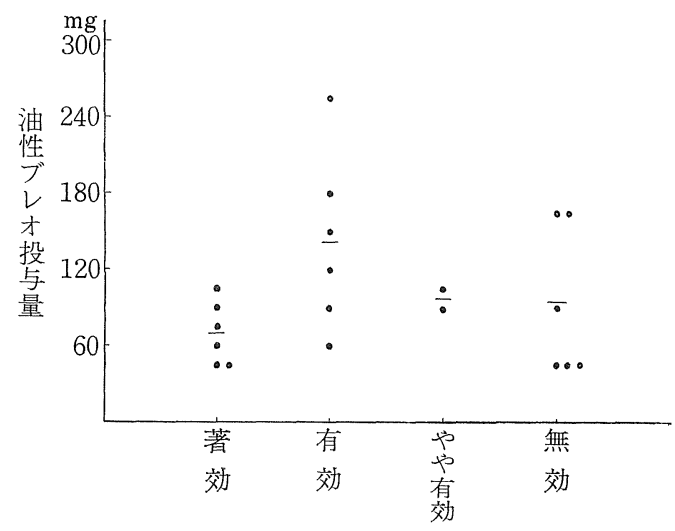

図 2

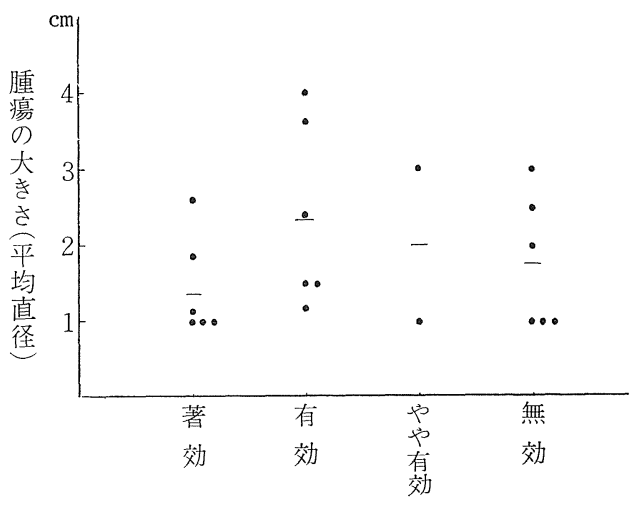

図 3

例

た（図 4)。再手術を考慮すると共に，それ迄 の期間油性 B LM局注を試みた。 6 回，105mg 局注を抢こなったところ腫瘍は肉眼的に消失し た。しかし右煩部痛が持続し可視範囲以外への 腫愓浸潤の可能性も考えられるため，8月 27 日，再度，上顎部分切除術を施行した。術後摘 出標本について病理組織学的検索を抢てなった が癌細胞はみとめなかった（図 5 )。現在，煩 
部狱屯消失し経過良好である。

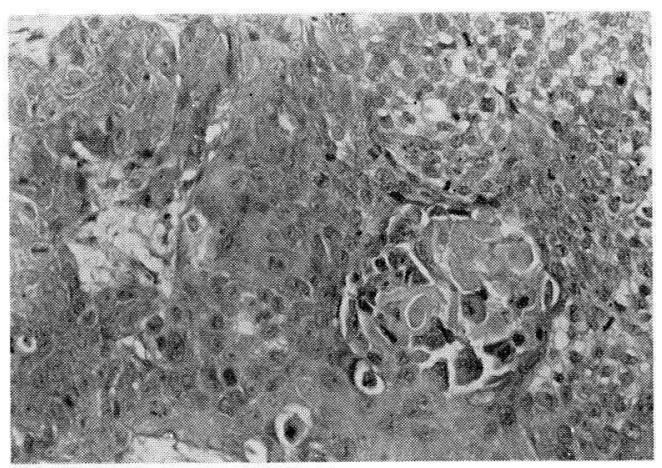

図 4 症例 1 局注前

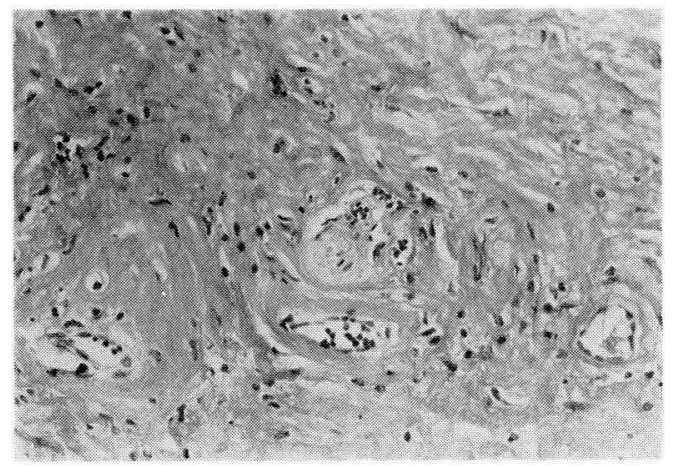

図 5 症例 1 局注後

症例 2 .

$60 才$ 男性

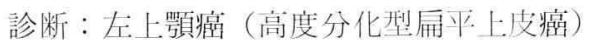
$\mathrm{T}_{2} \mathrm{~N}_{0} \mathrm{M}_{0}$

治療：昭和 49 年 3 月 7 日より B LM動注: $300 \mathrm{mg}$ 拉こない口内法により上顎全摘術老施行した。

4 力月後口蓋断端部及び鼻中隔部に腫揚の再発 在みとめたため 9 月 6 日，再発腫痬摘除術老お こなった。その後, 再び無症状に経過していた が， 7 力月後，眼窩下縁に腫演の再発をみ上め 炤和 50 年 4 月 23 日, 眼摘屯含めた腫湯切除術孝 おこなった。しかしながら 4 力月後に眼水外側 部付近に腫瘍の再発をみよめため，8月27日 より油性B LMの局注: 存開始した（図6）。6 回, $90 \mathrm{mg}$ 施行した時点で腫湯は著明に縮小し たが (図 7 ) 更に Gold grain の刺入走追加し 現在治療状態にある。

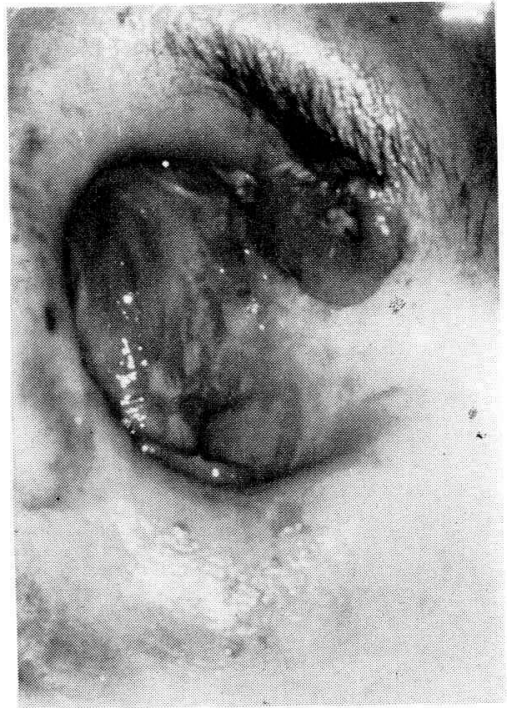

図 6 症例 2 局注前

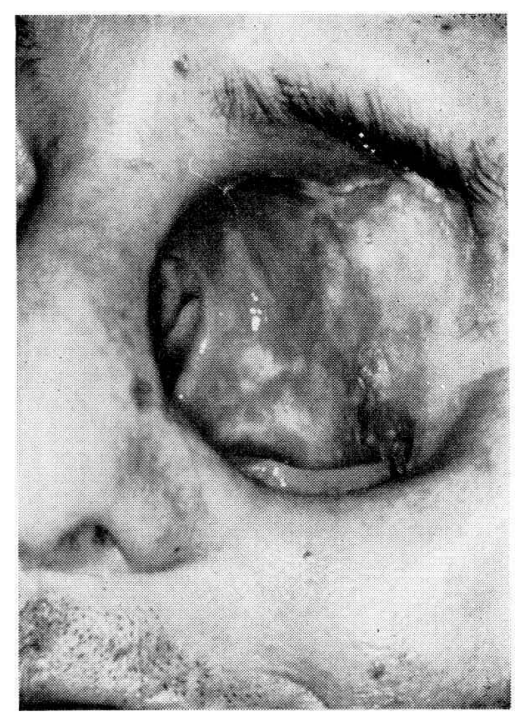

図 7 症例 2 局注後

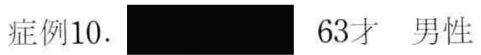

診断：口盍癌（分化型扁平上皮癌） $\mathrm{T}_{3} \mathrm{~N}_{0} \mathrm{M}_{0}$ 治療：昭和50年 3 月 30 日より B LM静注 $45 \mathrm{mg}$ と $\mathrm{Co}^{60} 5000 \mathrm{R}$ 照射にて腫瘍は殆んど消失した が，尚わずかに腫瘍の残存在みとめるため 6 月 16日より 3 回，75mg，油性B LM局注を执とな った。その後局所は般痕状に治僚し再発をみ上 めていない. 
症例 11 .

75才男性

診断：而癌（分化型局平上支癌） $\mathrm{T}_{1} \mathrm{~N}_{0} \mathrm{M}_{0}$ 治䝤：約 1 力月前加ら舌緣に $1.0 \times 1.0 \mathrm{~cm}$ の溃瘍 在みよめた。 biopsy の結果，㼛头上皮癌亡の 診断在得た。上ころが本人及び家病が手術，放 射線治療在望まなかったとと，及び高分である ため通常のB LM静注では肺線維症の危険性す あると考え，油性B LM局注在武みた。3回， $45 \mathrm{mg}$ の侍点で腄瘍は肉腿的に消失した。その後 現在迄は全く，無症状で経過している。

症例12.

54才男性

診断：口腔底癌（高度分化型徧头上皮㽞） $\mathrm{T}_{2}$ $\mathrm{N}_{1 \mathrm{a}} \mathrm{M}_{0}$

治療：患者は月硬変症に罹忠して抢り，于術瘏 法は闲難であるため放射線療法在中心とした治 療在予定した。そこで照射前に少しで屯腫瘍在 縮小させておきたいという考えから炤和50年 7 月4 日より油性B LM局注在開始した。3问， 60mgにて腫瘍は著明に繀小した（威９）。

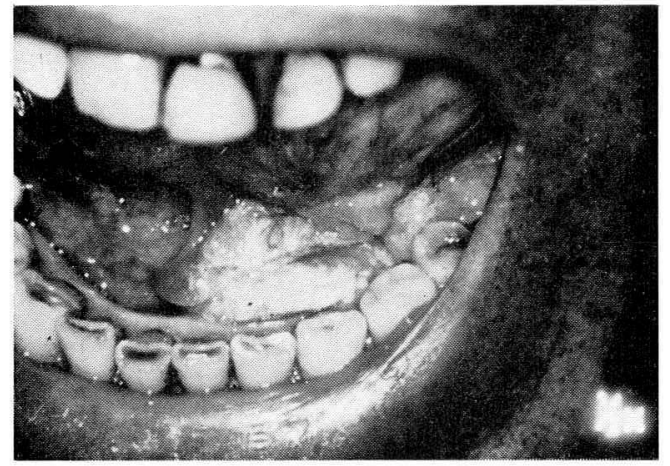

図 8 症例 12 局注前

尚 3 回目の局注の 3 日前より Linac 紧射も 開始しておう Linac. 600R 在併用したととに なる。その後は照射単独で $2400 \mathrm{R}$ 迄照射したが 口内炎がつよくなり患者が放射線療法在拒否し たため治潦在川止した。9月10日診祭㭙。尚， わずかに腫瘍が残存しているため，追扣照射在 すすめたが，これを拒否しその後は来院してい ない。

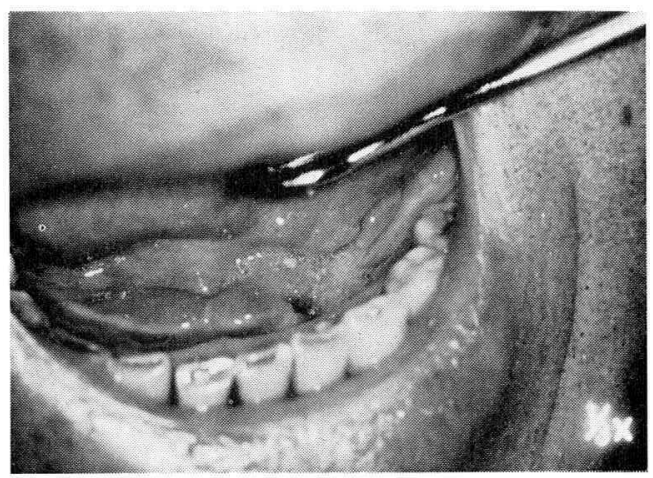

図 9 症例12 局注後

\section{症例13. 74才 男性}

診断：门蓋癌（高度分化型洏恢皮㽞） $\mathrm{T}_{2} \mathrm{~N}_{3}$ $\mathrm{M}_{0}$

治療：眧和50年 5 月 19 日上り B LM静注 $45 \mathrm{mg}$ と Linac. 3200R の併用で原発紧は肉腿的に全く 消失した。しかし頸部転移巣は十分コントロー ルされなかったため頸部廓清術をすすめたが, こ机在拒否した。しかし7月30日には原発巣に 再発存みとめたため，油性B LM局注孝開始し た（図10，11）。3回，45mg の時点で腫瘍は全 く消失した。この部の biopsy の結果でも腫痬 細胞をみ上めなかった（図12.13）。一方原発 巣への局注により頸部転移巣も若下紡小在み上 めたが放射線療法在追㞦した。

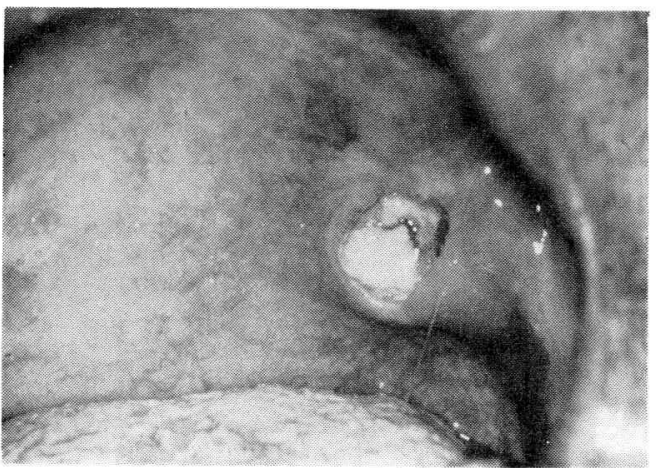

図10 症例13 局注前

\section{症例17. 58 才男性}

診断：喉頭癌（高度分化型扁头上皮癌） $\mathrm{T}_{2} \mathrm{~N}_{0}$ $\mathrm{M}_{0}$ 


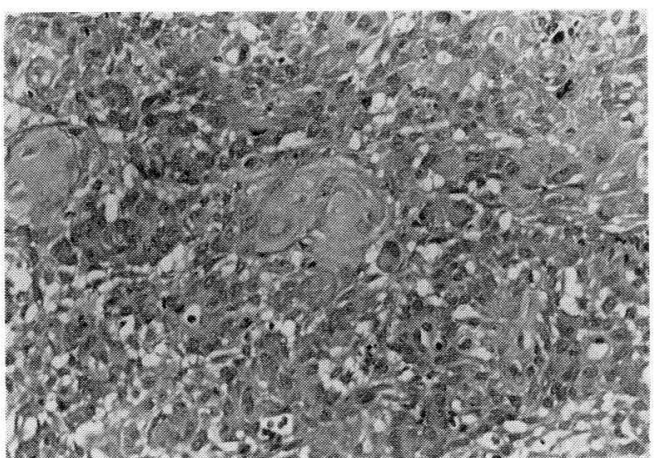

図।I 症例13 局注前

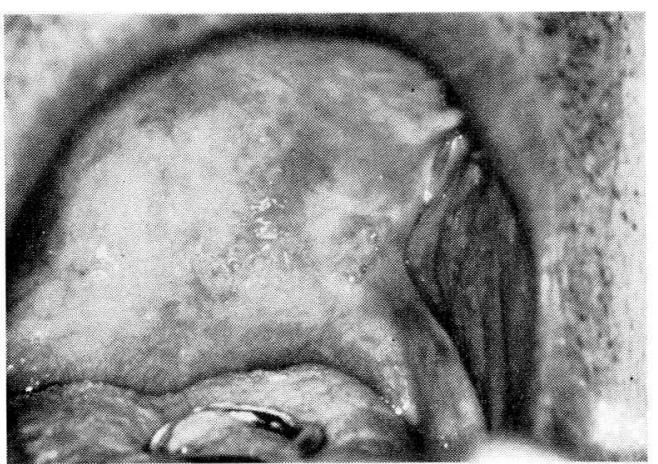

図 I2 症例 13 局注後

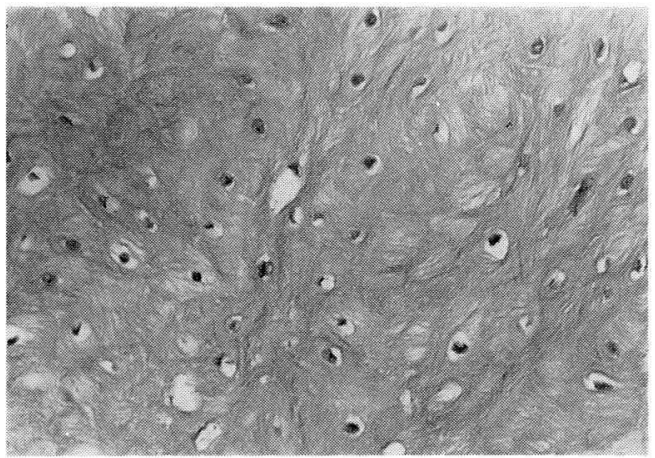

図１3 症例13 局注後

治療：昭和48年10月11日喉頭部分切除術施
行. しかし 5 力月後再発在み上め昭和 49 年 4 月 3 日. 聅韻全摘術施行。9 力月後左頸部リンパ 邻に軽移をみとめたため頸部廓清術施行し，術 後にB LM静注 $60 \mathrm{mg}$ と Linac. $2000 \mathrm{R}$ 想射在抒 こなった。炤和50年 3 月左頸部に再発圭子亡め たため入院. 検查の結果，手術不可能亡判断 L, 多剂併用療法（B LM，EX N , MM C, $5 \mathrm{FU}$ ) 及び $\mathrm{OK}-432$ 注射在おこない腫瘍の増 大は停止した（网14）。昭和50年 6 月 1 日より 油性 B LM局注開始. 3 回，90mg投与により腫 瘍は䌨小傾向在示したが（図15）3回目の局注 の2 日後に頸動脈破裂在来し死しした。

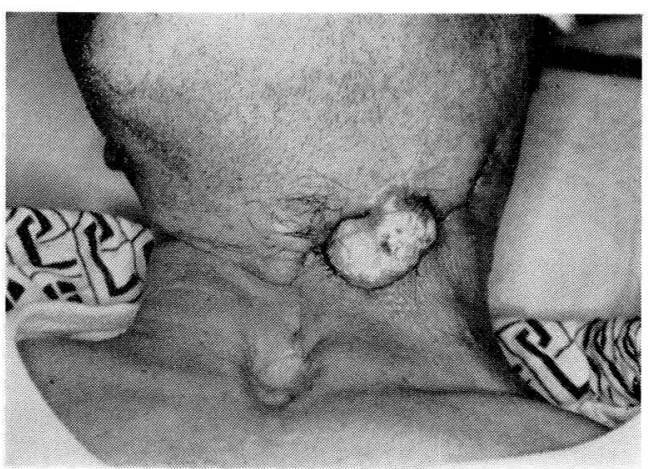

図I4 症例17 局注前

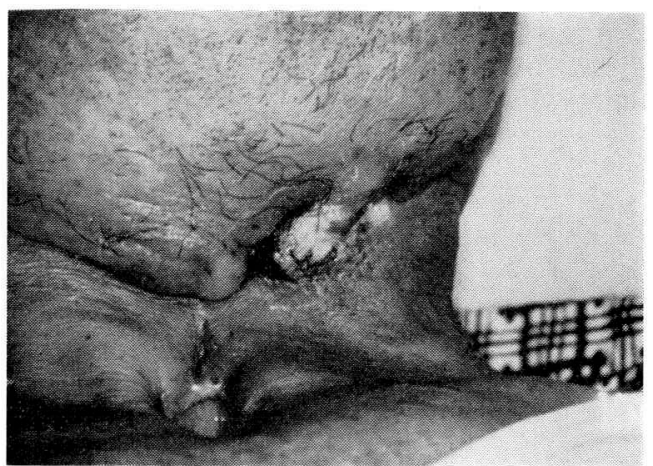

図I5 症例17 局注後

\section{6. 副作用}

油性 B LM局注療法における副作用は表 3 に 示すごとくである。20例中何らかの副作用在み 上めたものは15例で発現率は75\%であった。副
作用の内訳はやはり注射に伴う疼痛が最も多く 10例 $(50 \%)$ ，次いで発熱，全身倚䓌感が各7 例 $(35 \%)$ ，食欲不振が 5 例 $(25 \%)$ の順であ 
表 3 副作用

\begin{tabular}{|c|c|c|c|}
\hline 局所疼痛 & & 10 & $50 \%$ \\
\hline 発 熱 & & 7 & $35 \%$ \\
\hline 全身僚意感 & & 7 & $35 \%$ \\
\hline 食欲不振 & & 5 & $25 \%$ \\
\hline 肺症状 & & 0 & \\
\hline 頸動脈破裂 & & 1 & \\
\hline \multirow{2}{*}{ 副 作 用 } & $(+)$ & $15 / 20$ & $75 \%$ \\
\hline & $(-)$ & $5 / 20$ & $25 \%$ \\
\hline
\end{tabular}

った。しかしながら肺症状を来した症例はみと めなかった，尚，副作用という範疇で言及する ことは必ずし屯適当ではないと考えるが症例17 の喉頭癌頸部転移例に求いて油性 B LM局注 3 回で腫演の 60〜 70\%の縮小をみとめたが，3 回目の注射の 2 日後, 頸動脈破裂を来し死亡し た。

\section{7. 総括及び考按}

\section{1）投与方法について}

油性B LMの投与量及び投与間隔について は，著者らは 1 回15-30mg（1～2 ml）を週 1 回局注するととを原則としておてなってきた が，油性 B LMは従来の水溶性 B LM 比し局 所残留性が高いので, この程度の間隔, 投与量 で十分であるうと考えている。しかし本法をお こなっていく内にいくつかの問題点が見出され た。即ち，(1)注射の際の漏れ(2)局注時の疼痛(3) 腫瘍周囲に注射するか腫瘍内に注射するか，な ごである．先づ注射の際の漏れについて考えて みると著者らの症例に损いて予定した投与量を 正確に注射出来た症例は殆んどないと云っても 過言ではなく，注射部位や方法によっても楽液 の漏れが異なり投与量が変動していることが考 えられ静注や筋注の場合の様に薬剂が均等に分 布しない欠点がみとめられた。乙の問題は腫痬 の大きさにも関係して抢り腫瘍が大きいと薬剂 分布が更に不均等になり易い様に思われる. 次 に局注時の疼痛については著者らの20例の内, 約半数が疼痛を訴えた。特に腫瘍が皮膚の表面 に自潰していたり，浸潤しているょうな症例で その周囲から注射をする場合, 痛みがつよいと の印象を受けた。このような場合には予め 0.5 \%キシロカインにより浸潤麻酔をしておくとか なり疼痛を軽減出来るように思われる. 次に注 射の刺入部位であるが，初期の症例では腫瘍内 に注射した症例むあるが，やはり漏れが多いよ
うに思われ，その後の症例では出来るだけ腫瘍 の周困組織に注射するように心掛けている.

\section{2 ) 効果及び適応について}

著者らの乏しい経験からではあるが投与量と 効果との関係についてみる亡著効例での平均投 与量は70mgであるが，実際には $3 \sim 4$ 回の注射 で腫瘍が消失又はそれに近い効果を得たもの が多い。そ机に対し有効例では平均投与量は $142.5 \mathrm{mg}$ と多く，屯う少し局注をつづければあ っと効果が出るのではないかという期待から投 与量が増えたが結果的には腫瑒の縮小が $80 \%$ 以 上に至らなかった症例である。従って著者らは 注射回数としては 3 回，投与量としては45-90 $\mathrm{mg}$ が本治療法の限界之考え, この時点で腫瘍の 消失がみとめられる症例は本治療法の適応であ ったと考えられるし，効果が不十分なあのは直 ちに他の治療法に切り換えるべきであると考え る. 一方無効例での平均投与量が $92.5 \mathrm{mg}$ と少な いのは無効例 6 例中 3 例は 3 回局注を㧍てなっ た時点で疼痛がつよく注射を中止せざるを得な かった症例であり，むしろ判定不能例に入れる べきあのが含まれているためである．また腫瘍 の大きさと効果との関係については著効例での 腫瘍の平均直径は $13.7 \mathrm{~mm}$ でりやはり小さい腫 瘍の方が効果が大であることを示している．次 に疾患と効果との関係をみると口腔, 中咽頭癌 飞著効例が多く，本法の最む良い適応であろう 
と思われる。また上顎癌再発例屯著効 2 例, 有 効 2 例であり口腔, 中咽頭㐭に次いで本法の良 い適応となると思われる。一方頸部転移癌の 内，特に皮膚に自㵅しているような症例では有 効 1 例, やや有効 1 例, 無効 2 例と余り良い成 績を示さなかった。しか屯症例17では局注 3 回 目の 2 日後に頸動脈の破裂を来して死亡してお り症例，18，20も局注を中止したのち腫瘍が急 速に増大し，いずれも頸動脈破裂にて死亡し た。 また症例 5 は上顎癌再発例で顔面皮膚に腫 瘍が自潰していた症例であるが油性 B LM局注 により，初めの内はある程度腫瘍縮小傾向が窺 えたが中止後, 腫瘍が急速に増大し, 結局, 眼 球，患側の口唇，顔面皮膚屯含めた広汎な上顎 部全摘を余儀なくされた症例である。このよう に腫瘍が皮膚面に自潰している場合は，その自 潰部位は往々にして水山の一角であり，その深 部に扣いてはかなり，腫瘍の浸潤がつよいと考 えねばならない，従っててのような症例に対し て表面的にみえている部位だけを目標に局注を おこなっても腫瘍の大半は薬剂が分布していな 以可能性が高く治療中止後はかえって急速に腫 瘍が増大し，大出血を来したり思わ如結果を生 じる恐れがあるので注意が必要であろう。

次に油性 B LMを原発巣に注射した場合，局 所リンパ節にどの程度分布するかを，口腔底癌 の 1 例について検討を拈てなってみた。本例は $\mathrm{T}_{2} \mathrm{~N}_{0} \mathrm{M}_{0}$ の症例で B LM静注 30mg L Linac. 2600R照射の併用を抏こなったが， 【内炎がつ よく，治療を中止せざるを得なかった。しかし 尚，腫瘍が残存せるととと，本人の希望むあ り，根治手術を拈こなうことを決定した。そと で手術前日に油性 B LM30mgを原発巣に局注し ておき手術により摘出された標本について B L Mの組織内濃度を測定した。それによると患側 蕷下腺及び領下部リンパ節にかなり高濃度のB LMが測定された（表 4)。とのととは原発巣 に対する油性 B LM局注は頸部転移巣に対して あある程度効果を期待出来るととを示唆してい るものと思われる．乙の点については著者らの
表 4 左口腔底癌 52才 男

50. 7. 10. 10:50A.M. 油性 Bleo. 30mg局注

50. 7. 11. 10:00A ·M. 根治手術 血中濃度

7. 10 . 局注前 $<0.2 \gamma / \mathrm{ml}$

$5: 35 \mathrm{P} \cdot \mathrm{M} . \quad<0.2 r / \mathrm{ml}$

7. 11. $9: 30 \mathrm{~A} \cdot \mathrm{M} .<0.2 r / \mathrm{ml}$ 組織内濃度

7. 11. $1: 30 \mathrm{P} \cdot \mathrm{M}$. 左胸鎖乳突筋 $<0.4 r / \mathrm{g}$ 左顎下腺 $\quad 0.8 r / \mathrm{g}$ 顎下部リンパ節(1) $4.8 \mathrm{r} / \mathrm{g}$ 䫟下部リンパ節(2) $6.0 r / g$

$2: 00 \mathrm{P} \cdot \mathrm{M}$.

右顎下腺 $<0.4 r / \mathrm{g}$ 右顎下部りンパ節 $<0.4 r / \mathrm{g}$

症例 9，13に扣いて原発巣に対する油性 B LM 局注に際して頸部リンパ節の縮小傾向をみとめ たことを併わせ考えると甚だ興味樑い．

以上の結果よりあらためて油性 B LM局注療 法の効果, 適応につき検討してみると, 本法に より得られた臨床効果は, クライオサージャリ 一や Rn seed, Gold grain などの小線源照射 であ期待出来るあのであろうと思われる。しか し本法は特別の設備む必要とせず，放射性物質 の取波いが㛜重になった昨今を考える時，その 治療手技はきわめて簡便であるという長所を有 している. 従って本法の治療効果に対する限界 をわきまえ，適応を考えておてなうならば，補 助療法として十分意義ある屯のと考える. 著者 らの乏しい経験から敢て本法の投与方法, 適応 をまとめてみると次の如くである。

(1)油性 B LM局注療法の 1 回投与量は15一-30mg $(1 \sim 2 \mathrm{ml})$, 投与間隔は週 $1 \sim 2$ 回が適当 である。

(2)局注は腫瘍周囲組織におこない疼痛を訴える 患者では予め $0.5 \%$ キロカインにて浸潤麻 酔を抏てなうことが望ましい。

(3)腫瘍の大きさとしては平均直径で $1.5 \mathrm{~cm}$ 以内 の症例を選ぶことが望ましい。 
(4)著者らは治療法の限界を注射回数 3 回，投与 量45-90mg と考えており，乙の時点で十分な 効果が得らないものは，深追いするととな く，直ちに他の治療法に切り換えるべきであ ると考える。

(5)本法の最屯良い適応疾患は口腔癌, 中咽頭癌 などであり，上顎癌あ比較的良い適応であ る。乙れに対し腫痬が皮膚に自潰している症 例では本法による治療成績は悪く，しかも頸 部転移例では局注による急速な壊死に伴なう 頸動脈破裂の危険がある。
(6)本治療法の対象は再発癌を原則とすべきであ り，新鮮例では諸事情により根治手術や放射 線治療が出来ない症例などきわめて限られた 症例にとどめるべきであろう。

尚，本稿においては油性 B LMの局注療法の みについて言及したが著者らは本剂の筋注と放 射線療法との併用や上顎癌開洞時に本剂を浸し たガーゼを腫湯面に当てておく方法などあ試み 興味ある結果を得ているが，ての点については 別の機会に発表の予定である。

\section{8. 結語}

再発癌を中心とする頭頸部悪性腫痬 20 例に油性 B LM局注療法をおこない著効率 $30 \%$ ，有効率 60 \%の治療成績を得た。

本治療法の対象は原則として再発癌であり, 適応疾患としては口腔癌, 中咽頭癌, 上䪽癌などが あげられる．腫痬の大きさは平均直径で $1.5 \mathrm{~cm}$ 以内のものが望ましく，また局注回数，投与量から みた本法の限界は局注回数 3 回，投与量 45-90mg と考えられ，乙の時点で十分な効果が得られない あのでは直ちに他の治療法への切り換えが必要であろう.

尚，本治療法については今後(1)注射時の薬液の漏れ，(2)注射時の疼痛，(3)注射部位の選択などの 問題につき検討が必要であると考える.

稿を終るに臨み, 御校閲を頂いた斉藤成司教授に深謝致します. 尚本論文の要旨は第 4 回日耳鼻東京地方部会 にて発表した。

文

1 ）鈴木安恒, 三宅浩郷, 坂本裕, 犬山征夫, 他 : 頭 頸部悪性腫瘍に対するブレオマイシンの使用 経 験. 耳喉. $40 ： 1015-1020 ， 1968$.

2 ) Suzuki, Y., Miyake, H, Sakai, M., Inuyama, Y., Matsukawa, J. and Fujii, K. : Bleomycin in malignant tumors of head and neck. Keio J. Med., 18: 153-162, 1969.

3 ) 鈴木安恒, 犬山征夫：頭頸部悪性腫場に対する化 学療法. 綜合臨床. $20 ： 1396-1400,1971$.

4 ) 高崎敬：上顎癌に対する化学療法の臨床的並びに 病理組織学的研究. 日耳鼻. $74: 1129-1147$, 1971.

\section{献}

5 ) 犬山征夫, 三宅浩郷, 早崎弘晃：鼻咽腔悪性腫場 の治療方針とその成績.耳堠. $44: 179-188$, 1972.

6 ）藤井一省：頭頸部悪性腫痬に対する制癌剤治療に ついての臨床的研究. 耳鼻臨床. 67:367-389, 1974.

原稿到着: 昭和 51 年 2 月 2 日 別刷請求先：犬山征夫

齿 160 東京都新宿区信濃町 35 慶応義塾大学医学部耳鼻咽喉科学教室 